\title{
KONDISI SANITASI PERALATAN DAN HIGIENE BAHAN MINUMAN TERHADAP KEBERADAAN BAKTERI Eschericia coli PADA ES TEH DI WARUNG KELURAHAN MULYOREJO, SURABAYA
}

\section{THE SANITARY CONDITION OF EQUIPMENT AND THE HYGIENE OF BEVERAGE INGREDIENTS TO THE EXISTENCE OF ESCHERICHIA COLI BACTERIA IN ICE TEA FROM STALLS IN KELURAHAN MULYOREJO, SURABAYA}

\author{
Lisa Fitria Ningrum $1^{1}$, Lilis Sulistyorini ${ }^{2}$ \\ ${ }^{1}$ Puskesmas Bontang Utara J1. A. Yani RT13 Bontang, Kalimantan Timur, Indonesia \\ ${ }^{2}$ Departemen Kesehatan Lingkungan, Fakultas Kesehatan Masyarakat, Universitas Airlangga, Surabaya, \\ Indonesia \\ Alamat Korespondensi: Lisa Fitria Ningrum \\ E-mail:lisafitria7395@gmail.com
}

\begin{abstract}
Food stall is one of catering services that provide food/beverages for the public. The handling of utensils and selecting good food and beverages are the efforts to prevent the presence of Escherichia coli on food and beverages in the food stalls. The study aims to describe the process of handling the utensils, selecting food ingredients, and testing the presence of Escherichia coli in iced tea. The method of this research was crosssectional with 34 unit samples of food stalls in Mulyorejo Urban Village. The samples were inserted in plastic and tested in the laboratory with the Escherichia coli parameter. The interviews were conducted with the food vendors regarding the sources of clean water, the washing process, handling the utensils, and the iced tea ingredients, such as drinking water, tea, sugar, and ice cubes. The analysis was conducted in a descriptive approach. The results showed that $24 \%$ of the samples were positive containing Escherichia coli. The sellers' primary source of clean water was derived from the the Water Company (PDAM) by 82.3\%. Furthermore, $67.6 \%$ of the samples used detergent/soap in the washing process with two buckets, used to dip the utensils repeatedly. In terms of storing the utensils, $94.1 \%$ of the the utensils were glassware stored face down. The ingredients of iced tea consisted of boiled water (50\%), obtained from the well and the Water Company (PDAM), the tea ingredients which had been registered in food control agency, the sugar which was not spoiled or smelled, and the ice cubes which were bought from the neighborhood area (88.2\%). It is proven that Escherichia coli existed in the iced tea due to the sanitary components of utensils and the hygiene of beverage ingredients did not meet the requirements. It is recommended that the guidance can be given to the vendors, especially in washing the utensils correctly and selecting the beverage ingredients, such as water and ice cubes.
\end{abstract}

Keywords: Ice tea stalls, Escherichia coli, sanitary utensils, hygienic ingredients

\begin{abstract}
ABSTRAK
Warung merupakan jasa boga yang menyediakan makanan/minuman untuk kepentingan umum. Penanganan peralatan dan bahan makanan/minuman yang baik merupakan salah satu upaya mencegah keberadaan bakteri Eschericia coli dalam makanan/minuman yang dijual di warung. Tujuan penelitian adalah mendeskripsikan gambaran proses penanganan peralatan dan bahan makanan/minuman serta pengujian keberadaan bakteri Eschericia coli dalam es teh. Metode penelitian adalah cross sectional dengan besar unit sampel 34 warung di Kelurahan Mulyorejo. Sampel es teh kemudian dimasukkan di dalam plastik dan diujikan di laboratorium dengan parameter Eschericia coli. Wawancara dilakukan kepada 34 pedagang mengenai sumber air bersih yang digunakan, proses pencucian, cara penanganan peralatan dan penggunaan bahan pembuatan teh seperti air, teh, gula, dan es batu. Analisis dilakukan secara deskriptif. Hasil menunjukkan bahwa sebanyak 24\% sampel positif Eschericia coli. Sumber air bersih terbanyak yang digunakan pedagang adalah PDAM (82,3\%), sebanyak 67,6\% pencucian telah menggunakan detergen/sabun namun menggunakan 2 ember yang dicelupkan berulang, dan sebanyak $94,1 \%$ penataan peralatan minuman seperti gelas dilakukan telungkup. Pada bahan pembuatan es teh, sebanyak 50\% menggunakan sumber air bersih seperti sumur dan PDAM yang telah direbus dahulu, bahan teh yang digunakan telah terdaftar di lembaga perizinan, kondisi gula tidak rusak, tidak bau dan tidak berair serta penggunaan es batu sebagian besar membeli es batu rumah tangga (88,2\%). Keberadaan bakteri Eschericia coli di es teh menunjukkan bahwa masih terdapat komponen sanitasi peralatan dan higiene bahan minuman yang tidak memenuhi syarat. Diharapkan adanya pembinaan kepada pedagang terutama cara pencucian peralatan yang benar dan pemilihan bahan minuman seperti air minum dan es batu yang baik.
\end{abstract}


Kata kunci: Warung es teh, Eschericia coli, sanitasi peralatan minuman, higiene bahan minum

\section{PENDAHULUAN}

Warung makan adalah salah satu jasa boga dimana lingkup kegiatan yang menyediakan makanan dan minuman untuk kepentingan umum (Peraturan Menteri Kesehatan No 1098 Tahun 2003). Warung makan adalah salah satu tempat umum yang ramai pengunjung dimana kegiatan yang ada di warung makan hampir berlangsung sepanjang hari (Marissa dan Arifin, 2014). Seiring perkembangan zaman, aktivitas manusia semakin meningkat, hal ini membuat manusia akan lebih memilih cara praktis dalam pemenuhan kebutuhan pangan mereka (Sawong et al., 2016). Meningkatnya kebutuhan masyarakat mengenai kebutuhan pangan yang praktis harus diimbangi dengan usaha penyediaan makanan bagi kepentingan umum (makanan jajanan) yang terjamin keamanan dan kesehatannya (Yunus et al., 2015). Makanan jajanan merupakan makanan atau minuman yang diolah ditempat, disajikan secara langsung (siap santap) dan dijual kepada masyarakat umum (Depkes RI, 2006). Makanan jajanan yang dijual seharusnya memenuhi persyaratan Higiene dan sanitasi makanan jajanan yang baik (Rahmani dan Handayani, 2016). Hal ini diperlukan karena pemenuhan kebutuhan pangan yang baik merupakan salah satu syarat pencapaian derajat kesehatan optimal (Kusumawati dan Yudhastuti, 2013). Bakteri Eschericia coli merupakan bakteri fekal yang biasanya digunakan sebagai indikator mikrobiologis pencemaran pangan (Rahmani dan Handayani, 2016). Bakteri Eschericia coli di dalam air juga memiliki keterkaitan dengan adanya bibit penyakit. Masuknya Bakteri Eschericia coli ke dalam tubuh manusia akan menyebabkan penurunan kesehatan manusia dan terjadi gangguan kesehatan seperti diare (Yunus et al., 2015). Bakteri Eschericia coli terutama pada strain O157:H7 dapat menyebabkan sakit perut, diare, berdarah, dan sindrom hemolitik uremik (Cabral, 2010). Menurut Permenkes No 1098/Menkes/SK/VII/2003 menyatakan bahwa keberadaan bakteri di dalam makanan tidak boleh lebih dari 0/gram makanan sedangkan pada minuman tidak boleh lebih dari 0/100 ml minuman. Higiene dan sanitasi makanan merupakan salah satu aspek yang sangat penting untuk menentukan kualitas makanan/minuman melalui indikator keberadaan bakteri Eschericia coli dalam makanan/minuman yang dapat menimbulkan penyakit akibat makanan (food borne disease) (Yunus et al., 2015). Peralatan pengolahan makanan merupakan alat yang digunakan dalam proses pengolahan maupun penyajian makanan (Permenkes No 1098/Menkes/SK/VII/2003). Perlengkapan atau peralatan yang digunakan dalam penyiapan dan penyajian pangan dapat berpotensi menjadi sumber kontaminasi (Motarjemi, 2003). Oleh karena itu peralatan yang digunakan seharusnya dibersihkan dengan benar karena kemampuan bakteri yang bisa tumbuh dalam makanan yang tersisa dan berpotensi mengontaminasi tahap pengolahan setelahnya (Adams dan Motarjemi, 2004). Bahan mentah merupakan salah satu sumber cemaran mikroba (Azari, 2013). Pemilihan bahan makanan yang baik merupakan salah satu prinsip Higiene dan sanitasi yang perlu diperhatikan dalam pengolahan pangan (Depkes RI, 2004) dimana bahan pangan seharusnya dalam kondisi baik, tidak rusak, membusuk, dan berasal dari sumber resmi yang terawasi (Permenkes No 1098/Menkes/SK/VII/2003). Penelitian pernah dilakukan oleh Agustina, 2011 yang meneliti hubungan antara sanitasi alat dengan keberadaan bakteri Eschericia coli. Hasil menunjukkan bahwa terdapat hubungan antara sanitasi alat dengan keberadaan Eschericia coli dengan $p$ 0.042. pada penelitian yang sama dengan variabel bahan makanan, agustina menyimpulkan juga terdapat hubungan 
antara sanitasi bahan dengan keberadaan Escheicia coli dengan $p$ 0.015. Oleh karena itu, peneliti tertarik untuk meneliti kondisi peralatan dan bahan makanan terhadap keberadaan bakteri Eschericia coli di warung yang menjual es teh di Kelurahan Mulyorejo, Kota Surabaya.

\section{METODE PENELITIAN}

Jenis penelitian ini adalah penelitian deskriptif dengan desain penelitian cross sectional. Penelitian ini dilakukan selama 3 bulan. Populasi dalam penelitian ini adalah seluruh warung di Kelurahan Mulyorejo yang memiliki bangunan permanen sebesar 52. Berdasarkan hasil perhitungan menggunakan rumus lemeshow didapatkan besar sampel 34 warung. 1 warung merupakan satu unit sampel sehingga di dalam satu warung akan dilakukan wawancara terhadap 1 orang pedagang dan akan diambil pula 1 sampel es teh untuk diuji. Pengambilan sampel warung dilakukan dengan metode simple random sampling, kemudian dilakukan wawancara mengenai penggunaan air bersih, cara pencucian, penanganan peralatan, penggunaan air sebagai bahan minuman, bahan teh, kondisi gula, dan jenis es batu. Responden yang diwawancarai merupakan pedagang di warung yang menjual es teh. Sampel yang akan diujikan adalah es teh yang telah siap diminum. Seluruh sampel dimasukkan kedalam plastik dan ice box lalu dibawa ke laboratorium untuk diuji. Pengujian dilakukan dengan metode isolasi dan identifikasi untuk mengetahui ada tidaknya keberadaan bakteri Eschericia coli di dalam es teh. Penelitian ini telah memperoleh keterangan lolos kaji etik dari Komisi Etik FKM No : 302-KEPK.

\section{HASIL}

\section{Uji Kualitas Bakteriologis Es Teh}

Berdasarkan hasil pengujian laboratorium, didapatkan bahwa dari 34 sampel yang diujikan, sebanyak 8 (24\%) sampel positif bakteri Eschericia coli sedangkan $26 \quad(76 \%)$ sampel bernilai negatif bakteri Eschericia coli. Berdasarkan hasil pengujian dengan parameter bakteri Eschericia coli pada 34 sampel es teh di Warung Kelurahan Mulyorejo, didapatkan hasil sebagai berikut:

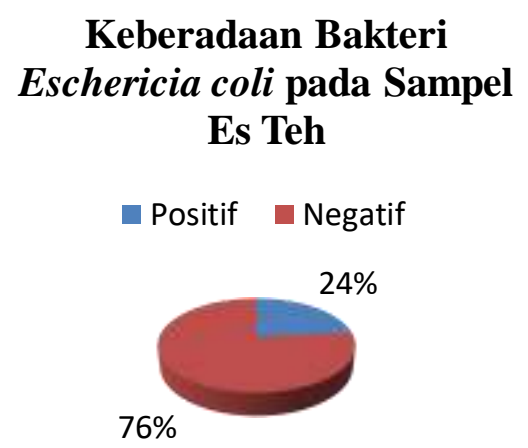

Gambar 1. Hasil Pengujian Keberadaan Bakteri Eschericia coli pada Sampel Es Teh

\section{Kondisi Sanitasi Peralatan Minuman Terhadap Keberadaan Bakteri Eschericia coli Sumber air bersih untuk mencuci peralatan}

Sumber air bersih merupakan sumber air yang digunakan pedagang dalam pencucian peralatan seperti gelas, teko, dan sendok. Sumber air bersih yang digunakan untuk mencuci peralatan ada 3 yakni PDAM, sumur, dan air gerobak dijual secara eceran. Berikut ini adalah jenis sumber air yang digunakan pedagang untuk mencuci peralatan dan keberadaan bakteri Eschericia coli pada minuman es teh.

Tabel 1 Sumber Air Bersih yang Digunakan Pedagang untuk Mencuci Peralatan

\begin{tabular}{lrrrrr}
\hline \multirow{2}{*}{$\begin{array}{c}\text { Sumber } \\
\text { air }\end{array}$} & \multicolumn{3}{c}{ Eschericia coli } & \\
\cline { 2 - 4 } bersih & \multicolumn{2}{c}{ Positif } & \multicolumn{2}{c}{ Negatif } & Total \\
\cline { 2 - 4 } & $\mathbf{n}$ & $\boldsymbol{\%}$ & $\mathbf{n}$ & $\boldsymbol{\%}$ & \\
\hline PDAM & 6 & 21,4 & 22 & 78,6 & 100,0 \\
Sumur & 2 & 50,0 & 2 & 50,0 & 100,0 \\
Gerobak & 0 & 0,0 & 2 & 100,0 & 100,0 \\
\hline
\end{tabular}


Sumber air bersih yang paling banyak digunakan pedagang untuk mencuci peralatan makan/minum adalah air PDAM yakni sebanyak 28 pedagang. Dari 28 warung yang juga diambil sampel pada es teh tersebut, sebanyak 6 sampel $(21,4 \%)$ positif mengandung bakteri Eschericia coli. Sedangkan dari 4 warung yang menggunakan sumber air bersih sumur, sebanyak 2 sampel (50\%) positif mengandung bakteri Eschericia coli. Sumber air bersih lain yang digunakan pedagang adalah air yang dibeli secara eceran dengan gerobak. Dari 2 warung yang menggunakan sumber air bersih gerobak, tidak ditemukan bakteri Eschericia coli pada es teh.

\section{Penggunaan sabun saat pencucian peralatan dengan keberadaan bakteri}

Penggunaan sabun/detergen pada saat pencucian peralatan minum merupakan kebiasaan penggunaan sabun/detergen oleh pedagang dalam pencucian peralatan minum seperti gelas, sendok, dan teko apakah menggunkaan sabun atau tidak.

Tabel 2 Penggunaan Sabun Saat

\begin{tabular}{|c|c|c|c|c|c|}
\hline \multirow{4}{*}{$\begin{array}{l}\text { Penggunaan } \\
\text { Sabun/ } \\
\text { detergen }\end{array}$} & \multicolumn{5}{|c|}{ Pencucian Peralatan minum } \\
\hline & \multicolumn{4}{|c|}{ Eschericia coli } & \multirow{3}{*}{ Total } \\
\hline & \multicolumn{2}{|c|}{ Positif } & \multicolumn{2}{|c|}{ Negatif } & \\
\hline & $\mathbf{n}$ & $\%$ & $\mathrm{n}$ & $\%$ & \\
\hline Ya & 7 & 23,3 & 23 & 76,7 & 100,0 \\
\hline Tidak & 1 & 25,0 & 3 & 75,0 & 100,0 \\
\hline
\end{tabular}

menggunakan sabun/detergen dalam pencucian peralatan dan hanya 4 pedagang yang tidak menggunakan detergen dalam pencucian peralatan. Peralatan makan hanya dicelupkan ke dalam timba tanpa direndam, digosok dengan detergen, dan dibilas terlebih dahulu. dari 30 pedagang yang menggunakan sabun saat pencucian peralatan, sebanyak 7 sampel $(23,3 \%)$ pengujian menunjukkan positif bakteri Eschericia coli. Sementara dari 4 pedagang yang melakukan pencucian peralatan makanan/minuman tanpa mengunakan sabun/detergen, terdapat 1 sampel $(25 \%)$ yang positif mengandung bakteri Eschericia coli.

\section{Proses pencucian peralatan}

Proses pencucian disini merupakan tahap pencucian yang dilakukan oleh pedagang dalam mencuci peralatan minum. Proses pencucian yang dilakukan pedagang terdiri dari berbagai cara yaitu pencucian dengan air mengalir, pencucian menggunakan 3 bak yang terdiri dari tahap perendaman, penggosokan, dan pembilasan, proses pencucian menggunakan 2 bak yang terdiri dari penggosokan dan pembilasan, serta peroses pencucian dengan 1 bak yang hanya dicelupkan tanpa diberi detergen. Proses pencucian peralatan yang dilakukan pedagang dalam mencuci perlatan dijelaskan dalam Tabel 3.

Tabel 3 Proses Pencucian Peralatan yang Dilakukan Pedagang

\begin{tabular}{|c|c|c|c|c|c|}
\hline \multirow{3}{*}{$\begin{array}{c}\text { Cara } \\
\text { Pencucia } \\
\text { n }\end{array}$} & \multicolumn{4}{|c|}{ Eschericia coli } & \multirow{3}{*}{ Total } \\
\hline & \multicolumn{2}{|c|}{ Positif } & \multicolumn{2}{|c|}{ Negatif } & \\
\hline & $\mathrm{n}$ & $\%$ & $\mathrm{n}$ & $\%$ & \\
\hline $\begin{array}{l}\text { Air } \\
\text { mengalir }\end{array}$ & 1 & 25,0 & 3,0 & 75,0 & 100,0 \\
\hline 3 Bak & 0 & 0,0 & 1,0 & 100,0 & 100,0 \\
\hline $2 \mathrm{Bak}$ & 7 & 30,4 & 16,0 & 69,6 & 100,0 \\
\hline $1 \mathrm{Bak}$ & 0 & 0,0 & 6,0 & 100,0 & 100,0 \\
\hline
\end{tabular}

Sebagian besar pedagang melakukan proses pencucian dengan menggunakan 2 bak dengan proses penggosokan dan pembilasan tanpa disertai perendaman. Dari 23 pedagang yang melakukan pencucian dengan cara demikian, sebanyak 7 sampel $(30,4 \%)$ positif Eschericia coli. Sementara itu sebanyak dari 4 pedagang yang melakukan pencucian peralatan menggunakan air mengalir, 1 sampel (25\%) diketahui positif Eschericia coli. Dari 34 pedagang, hanya 1 pedagang yang mencuci peralatan menggunakan 3 bak melalui proses perendaman, penggosokan, lalu pembilasan, dan hasil uji sampel menunjukkan negatif Eschericia coli. Namun masih ada pedagang yang mencuci 
peralatan mereka menggunakan 1 bak dengan dicelupkan tanpa diberi sabun, sedangkan pengujian sampel meunjukkan hasil negatif.

\section{Penataan peralatan}

Penataan peralatan merupakan cara pedagang dalam memperlakukan dan menyimpan peralatan makan/minum setelah dilakukan pencucian. Penataan peralatan seperti gelas dapat ditata secara terbalik diatas tatakan maupun dikumpulkan di dalam baskom besar. Penataan peralatan dengan terbalik/telungkup akan membuat peralatan menjadi cepat kering namun apabila penataan peralatan tidak dilakukan terbalik akan memperlambat proses pengeringan kecuali dilakukan pengelapan terlebih dahulu. Sebanyak 32 pedagang $(94.1 \%)$ telah melakukan penataan gelas dan teko dalam keadaan terbalik dan disimpan diatas tatakan yang terbuka sehingga sisa air cucian bisa luruh dan alat menjadi cepat kering. Sementara 2 pedagang $(5,8 \%)$ melakukan penataan baik gelas maupun teko dengan dibaringkan di baskom besar.

\section{Kondisi Higiene Bahan Minuman Terhadap Keberadaan Bakteri Eschericia coli}

\section{Sumber air minum}

Sumber air minum merupakan sumber air yang digunakan pedagang sebagai bahan air untuk membuat teh. Berdasarkan hasil wawancara, terdapat 4 sumber air minum yang digunakan pedagang, diantaranya adalah air galon beli baru, air minum isi ulang, air matang, dan air mentah. Air galon beli baru berasal dari air galon yang selalu diganti baru, air isi ulang berasal dari Depot Air Minum Isi Ulang (DAMIU), air matang berasal dari air bersih yang telah direbus terlebih dahulu, sedangkan air mentah adalah air bersih tanpa direbus terlebih dahulu untuk membuat es teh. Berikut ini adalah sumber air minum yang digunakan pedagang berdasarkan jumlahnya.
Air yang paling banyak digunakan sebagai bahan pembuatan es teh adalah air matang yaitu sebanyak 17 warung $(50 \%)$ dan pengujian bakteri menunjukkan bahwa sebesar 3 sampel $(17,6 \%)$ bernilai positif. Selain itu sebanyak 2 pedagang $(5,8 \%)$ menggunakan air galon beli baru dan hasil pengujian sampel keduanya bernilai negatif. Sementara dari sebanyak 14 warung yang menggunakan sumber air minum isi ulang, terdapat 3 sampel $(21,4 \%)$ yang positif mengandung bakteri Eschericia coli. Masih terdapat 1 pedagang yang menggunakan air mentah untuk membuat es teh dan hasil pengujian menunjukkan nilai positif bakteri.

Tabel 4. Sumber Air Untuk Bahan Es Teh

\begin{tabular}{|c|c|c|c|c|c|}
\hline \multirow{3}{*}{$\begin{array}{l}\text { Sumber } \\
\text { air } \\
\text { minum }\end{array}$} & \multicolumn{4}{|c|}{ Eschericia coli } & \multirow{3}{*}{ Total } \\
\hline & \multicolumn{2}{|c|}{ Positif } & \multicolumn{2}{|c|}{ Negatif } & \\
\hline & $\mathbf{n}$ & $\%$ & $\mathbf{n}$ & $\%$ & \\
\hline $\begin{array}{l}\text { Beli } \\
\text { baru }\end{array}$ & 0 & 0,0 & 2 & 100,0 & 100,0 \\
\hline Isi ulang & 4 & 28,6 & 10 & 71,4 & 100,0 \\
\hline $\begin{array}{l}\text { Air } \\
\text { matang }\end{array}$ & 3 & 17,6 & 14 & 82,4 & 100,0 \\
\hline $\begin{array}{l}\text { Air } \\
\text { mentah }\end{array}$ & 1 & 100,0 & 0 & 0,0 & 100,0 \\
\hline
\end{tabular}

\section{Higiene bahan teh}

Bahan teh merupakan bahan teh yang digunakan oleh pedagang pada saat pembuatan teh. Bahan teh yang baik seharusnya terdaftar di lembaga perizinan seperti BPOM maupun dinas kesehatan. Berdasarkan hasil wawancara kepada pedagnag, didapatkan bahwa sebanyak 33 warung (97\%) menggunakan bahan teh dengan merek yang telah terdaftar di Depkes RI, sedangkan terdapat 1 warung (2.9\%) menggunakan merek teh yang tidak terdaftar di Depkes maupun BPOM, namun berdasarkan pengujian, sampel menunjukkan nilai negatif bakteri Eschericia coli.

\section{Kondisi fisik gula}

Kondisi fisik gula merupakan kedaan fisik gula yang digunakan pedagang sebagai bahan pembuatan es teh. 
Kondisi fisik dikatakan memenuhi apabila dalam keadaan tidak rusak, tidak bau, dan tidak berair. Seluruh sampel gula di warung telah memenuhi persyaratan kondisi baik, tidak rusak, dan tidak membusuk.

\section{Jenis es batu}

Es batu yang digunakan pedagang sebagai bahan pembuatan es teh terdiri dari 4 jenis yaitu es batu rumah tangga yang didapatkan dengan cara membeli, es kristal, es balok, dan membuat sendiri. Berikut ini merupakan hasil wawancara mengenai jenis es batu yang digunakan pedagang untuk membuat es teh.

Tabel 5. Jenis Es Batu yang Dipakai Sebagai Bahan Pembuatan Es the

\begin{tabular}{lccccc}
\hline \multirow{2}{*}{$\begin{array}{l}\text { Jenis Es } \\
\text { Batu }\end{array}$} & \multicolumn{4}{c}{ Eschericia coli } & \\
\cline { 2 - 4 } & \multicolumn{2}{c}{ Positif } & \multicolumn{2}{c}{ Negatif } & \multirow{2}{*}{ Total } \\
\cline { 2 - 4 } & \% & n & \% & \\
\hline Rumah & 5 & 17,8 & 23 & 82,2 & 100 \\
tangga & & & & \\
Kristal & 1 & 50,0 & 1 & 50,0 & 100 \\
Balok & 1 & 50,0 & 1 & 50,0 & 100 \\
Membuat & 1 & 50,0 & 1 & 50,0 & 100 \\
sendiri & & & & & \\
\hline
\end{tabular}

Sebagian besar pedagang menggunakan es batu plastik rumah tangga sebagai bahan minuman es teh yang mereka jual. Dari 30 pedagang yang menggunakan es batu plastik, sebanyak 28 pedagang mendapatkannya dengan cara membeli sedangkan sebanyak 2 pedagang membuat sendiri. Dari 28 es batu rumah tangga yang didapatkan dengan membeli, sebanyak 5 sampel $(17,8 \%)$ mengandung bakteri Eschericia coli. Sementara dari 2 es batu yang didapatkan dengan membuat sendiri, 1 sampel $(50 \%)$ bernilai positif bakteri dan 1 sampel (50\%) lainnya negatif. Selain es batu rumah tangga, jenis es batu lain yang digunakan pedagang adalah es batu kristal dan es balok. Dari 2 pedagang yang menggunakan es batu Kristal, sebanyak 1 sampel (50\%) mengandung bakteri sementara 1 sampel
(50\%) lainnya negatif. Dan dari 2 pedagang yang menggunakan es batu balok, pengujian sampel es teh menunjukkan 1 sampel $(50 \%)$ positif Eschericia coli dan 1 lainnya bernilai negatif.

\section{PEMBAHASAN}

\section{Uji Kualitas Bakteriologis Es Teh}

Pengujian dimana 8 sampel (24\%) bernilai positif mengandung bakteri Eschericia coli menunjukkan bahwa masih terdapat minuman yang tercemar bakteri Eschericia coli di warung yang menjual es teh di Kelurahan Mulyorejo, Kota Surabaya. Padahal seharusnya, keberadaan bakteri Eschericia coli harus bernilai nol dalam setiap $100 \mathrm{ml}$ air (Permenkes Nomor 1098/Menkes/SK/VII/2003) sehingga dapat dikatakan bahwa masih terdapat $8(24 \%)$ minuman yang tidak memenuhi Permenkes No 1098/Menkes/SK/VII/2003 pada parameter bakteri Eschericia coli. Penelitian serupa pernah dilakukan oleh Agustina (2011) yang meneliti "Hubungan antara Higiene penjamah dan sanitasi makanan dengan keberadaan Eschercia coli (Studi di warung jus buah sekitar kampus UNNES tahun 2011)". Hasil menunjukkan bahwa dari 21 sampel jus buah yang diuji, 15 menunjukkan positif bakteri Eschercia coli dan 6 sampel lainnya bernilai negatif. Penelitian lain dilakukan oleh Putri (2015) yang melakukan pemeriksaan kualitas mikrobiologi es batu pada es batu yang di jual di warung nasi Kelurahan Pisangan. Hasil menunjukkan bahwa $66,7 \%$ sampel mengandung Eschercia coli dan 88,9\% sampel memiliki nilai diatas ambang batas. Penelitian serupa dilakukan oleh Yanti (2014) yang menguji Eschercia coli pada es batu yang digunakan pedagang di sepanjang pantai purus kota padang dengan sampel es batu balok, es batu kristal, dan es batu plastik rumah tangga. Hasil menunjukkan bahwa ketiga sampel tersebut positif mengandung bakteri Eschercia coli. Bakteri Eschericia coli 
merupakan bakteri yang secara alami berada pada pencernaan manusia, namun jika keberadaannya berada diluar tubuh manusia merupakan indikasi tercemar oleh kotoran manusia (Kurniadi et al., 2013). Keberadaan bakteri Eschericia coli di dalam es teh mengindikasikan bahwa masih adanya kontaminasi es teh oleh tinja manusia di warung yang menjual es teh di Kelurahan Mulyorejo Kota Surabaya.

\section{Kondisi Sanitasi Peralatan Terhadap Keberadaan Bakteri Eschericia coli Sumber air bersih untuk mencuci peralatan}

Sumber air bersih sebagai pencucian peralatan penting diperhatikan karna dapat mempengaruhi kualitas makanan selanjutnya. Memang dalam air bersih, batas maksimum keberadaan bakteri Eschericia coli adalah 10/100 ml, namun keberadaan bakteri Eschericia coli dalam es teh dapat terjadi salah satunya karena faktor kebersihan peralatan. Karena menurut penelitian Agustina (2011), terdapat hubungan antara sanitasi alat dengan keberadaan bakteri Eschericia coli dalam minuman. Pencucian peralatan dengan air tercemar akan membuat peralatan turut tercemar. Peralatan makan seharusnya dicuci dengan bersih karena berpotensi menyebabkan bibit penyakit tertinggal, berkembang biak, dan mencemari makanan apabila pencucian tidak bersih (Tumelap, 2011). Pemasakan memang dapat mematikan bakteri patogen, namun apabila peralatan makan dicuci menggunakan air mentah yang tercemar akan sama dengan membilas dengan air tercemar walaupun menggunakan sabun (Tumelap, 2011). Sebagian besar $(82,3 \%)$ pedagang menggunakan sumber air PDAM karena memang sebagian besar warung pedagang berada di daerah strategis yaitu dipinggir jalan yang mudah dijangkau PDAM. Keberadaan bakteri Eschericia coli dimana proses pencucian peralatan menggunakan PDAM dapat terjadi karena sumber air PDAM sendiri yang telah tercemar. Salah satu faktor terjadinya pencemaran air pada sumber air PDAM adalah bocornya pipa, longgarnya sambungan antar pipa, dan tekanan di dalam pipa yang rendah sehingga memudahkan kotoran di luar pipa masuk ke dalam pipa dan mencemari air bersih (Tumelap, 2011).

Sumber air bersih lain yang digunakan adalah air sumur yakni sebesar 11,7\%. Keberadaan bakteri Eschericia coli pada sampel dimana menggunakan air sumur sebagai bahan pencucian peralatan dapat terjadi karena sumber air sumur sendiri yang tidak terlindungi sehingga air tercemar. Pencemaran air bersih yang menggunakan sumur dapat terjadi karena konstruksi sumur tidak memenuhi standar kesehatan dimana menurut Marsono (2009) bangunan sumur yang tidak memenuhi persyaratan kesehatan misalnya dinding tidak dibuat kedap air atau dilapisi beton akan membuat air sumur tercemar melalui air tanah yang merembes dan masuk melalui pori tanah, begitu pula dengan bibir dan lantai yang tidak dibangun. Selain itu kebiasaan manusia melakukan aktivitas rumah tangga dengan jarak yang berdekatan dengan sumur akan membuat air sumur terkontaminasi dengan sisa air yang telah digunakan.

Selain air PDAM dan air sumur, pedagang juga menggunakan air yang dibeli dari gerobak eceran untuk mencuci peralatan. Air gerobak adalah air yang diangkut dengan gerobak/ kuda/keledai, dan kendaraan bermotor yang dimasukkan kedalam jerigen (Badan pusat statistik 2015). Hasil pengujian sampel produk yang pencuciannya menggunakan air gerobak ini menunjukkan negatif. Hasil ini dapat disebabkan karena sumber air gerobak dorong ini sendiri biasanya adalah air PDAM yang diangkut dengan jerigen yang tertutup sehingga masih aman digunakan sebagai air bersih.

\section{Penggunaan sabun saat pencucian dengan keberadaan bakteri}

Peralatan yang bersih penting
dikonndisikan karena peralatan akan


bersentuhan langsung dengan makanan/minuman nantinya. Penggunaan sabun pada saat mencuci peralatan digunakan untuk menghilangkan kotoran pada peralatan yang berpotensi mengontaminasi minuman. Hasil penelitian juga menunjukkan bahwa sebanyak 4 pedagang $(11,7 \%)$ yang tidak menggunakan sabun saat pencucian, sebesar 1 sampel (25\%) positif mengandung bakteri. Hal ini menunjukkan bahwa kemungkinan minuman tercemar bakteri Eschericia coli pada minuman yang peralatannya tidak dicuci menggunakan sabun/detergen. Detergen berguna untuk melarutkan sisa makanan dan lemak di dalam peralatan makan (Depkes, 2006). Pencucian peralatan tanpa detergen akan memungkinan sisa makanan tertinggal didalam peralatan, padahal, sisa makanan yang tertinggal walaupun sedikit dapat memberi kesempatan kuman berkembang biak dan membusukkan makanan (Tumelap, 2013). Sementara itu, sebagian besar pedagang telah sadar akan pencucian menggunakan detergen/sabun pada peralatan. Detergen yang digunakan sebagian besar adalah detergen cair, namun masih ada yang menggunakan detergen bubuk. Pencucian menggunakan detergen cair akan lebih baik karena detergen cair sangat larut dalam air sehingga sangat sedikit kemungkinan sisa sabun yang membekas pada peralatan (Depkes, 2006).

\section{Proses pencucian peralatan}

Tahap pencucian peralatan memasak sebaiknya adalah perendaman, pengguyuran/penggosokan detergen, lalu pembilasan yang dilakukan di dalam 3 bak pencucian (Kepmenkes No 715/Menkes/SK/V/2003). Terbukti bahwa 1 pedagang $(2.94 \%)$ yang mencuci peralatan melalui 3 tahap tersebut tidak ditemukan keberadaan Bakteri Eschericia coli di dalam minumannya. Namun berdasarkan penelitian Azari (2013) pencucian peralatan makan dengan air mengalir lebih efektif menurunkan jumlah kuman dibandinkan dengan perendaman.
Hal itu dikarenakan pencucian dengan air mengalir akan melarutkan semua kotoran dan terbuang bersama air, sedangakan proses perendaman akan memungkinkan kotoran hasil bilasan terakumulasi di dalam bak dan dapat mencemari alat yang akan dicuci selanjutnya (Azari, 2013). Memang dari 4 pedagang $(11.7 \%)$ yang menggunakan air mengalir pada proses pencucian, hanya 1 sampel (25\%) yang positif bakteri Eschericia coli, hal ini dapat terjadi karena kemungkinan air yang digunakan memang telah tercemar karena pencucian peralatan dengan air yang tercemar akan turut mencemari peralatan tersebut. Cara pencucian terbanyak yang dilakukan pedagang adalah dengan menggunakan 2 bak berulang-ulang tanpa perendaman terlebih dahulu. Dari 24 pedagang $(67,6 \%)$ yang melakukan pencucian dengan cara tersebut, sebanyak 7 sampel produk $(30,4 \%)$ menganduk bakteri. Pencucian berulang-ulang akan membuat bakteri tertinggal dan mengotori peralatan yang akan dicuci selanjurnya. Menurut penelitian Isnawati (2012) air yang digunakan pada pencucian berulangulang tampak kotor sehingga pencucian dengan air bersih perlu untuk menjaga efektivitas pencucian.

\section{Penataan peralatan}

Sebagian besar pedagang telah melakukan penataan peralatan seperti gelas dan teko secara terbalik. Peralatan yang tidak ditata dalam keadaan terbalik adalah alat yang ringan seperti gelas plastik yang ditumpuk dalam satu baskom besar. Sebenarnya, penataan yang dilakukan secara terbalik adalah kemauan dari pedagang sendiri. Namun penataan peralatan minum dengan terbalik akan membuat peralatan menjadi lebih cepat kering tanpa dilakukan pengelapan terlebih dahulu. Penataan dilakukan secara terbalik maupun tidak terbalik tidak ada masalah yang terpenting adalah penyimpanan peralatan dilakukan dalam keadaan tertutup karena penyimpanan dalam keadaan tertutup akan mengurangi risiko 
kontaminasi binatang pembawa bakteri seperti lalat, tikus, dan kecoa (Marissa dan Arifin, 2014). Selain itu penyimpanan secara tertutup juga akan mencegah kontaminasi debu.

\section{Kondisi Higiene Bahan Minuman Berdasarkan Keberadaan Bakteri Eschericia coli Sumber air minum}

Air merupakan salah satu faktor yang menentukan kualitas produk es karena air sendiri digunakan untuk bahan baku pembuatan es dalam hal ini adalah es teh (Isnawati, 2012). Air bersih yang akan dikonsumsi sebaiknya dimasak terlebih dahulu dengan direbus sampai mendidih minimal 5 menit sehingga dapat membunuh bakteri yang ada di dalam air tersebut (Puspitasari dan Mukono, 2013). Karena bakteri Eschericia coli sendiri akan mati pada suhu $60^{\circ} \mathrm{C}$ dalam waktu 30 menit (Depkes, 1989) dan apabila waktu pemasakan dipersingkat, maka suhu pemasakan harus dinaikkan diatas $60^{\circ} \mathrm{C}$ (Ademi dan Rinanda, 2011). Keberadaan bakteri Eschericia coli pada es teh dengan sumber air bersih yang telah rebus dapat terjadi karena kurangnya waktu pemasakan air bersih sehingga masih ada bakteri yang belum mati. Namun berdasarkan pengujian keberadaan bakteri Eschericia coli, hasil positif terbanyak adalah pada sampel yang menggunakan bahan air isi ulang untuk membuat es teh. Dari 10 warung yang menggunakan air isi ulang, sebanyak 4 sampel (40\%) diketahui positif mengandung bakteri Eschericia coli. Sumber air minum yang digunakan dapat menjadi salah satu faktor keberadaan bakteri di dalam produk es teh. Air minum isi ulang merupakan salah satu solusi pemenuhan kebutuhan air, namun karena belum adanya standar peraturan proses pengolahan air, sehingga kualitasnya masih diperdebatkan (Marpaung dan Marsono, 2013). Menurut penelitian Marpaung dan Marsono, 2013 yang meneliti Depot Air Minum Isi Ulang (DAMIU) di Kecamatan Sukolilo, Kota Surabaya, didapatkan hasil bahwa dari 10 depot, terdapat 4 depot dalam kategori baik dan 6 depot dalam kategori cukup dalam perilaku pemeliharaan alat. Diantara keenam depot tersebut, sebanyak 4 depot belum memenuhi parameter total koliform, sehingga perilaku dan pemeliharaan alat yang baik akan mempengaruhi kualitas produksi air yang baik. Sementara itu masih terdapat pedagang yang menggunakan air mentah dalam pembuatan es teh. Hal ini tidak dibenarkan karena air mentah tidak diperuntukkan sebagai air minum. Proses pembekuan es tidak langsung membunuh bakteri. Bakteri Eschericia coli tumbuh baik pada suhu $8^{\circ} \mathrm{C}-46^{\circ} \mathrm{C}$.bila berada dibawah temperatur minimum maupun sedikit diatas temperatur maksimum, bakteri ini tidak segera mati, melainkan mengalami dorman (Misnadiarly, 2014). Hasil pengujian menunjukkan sampel positif mengandung bakteri Eschericia coli. Konsumsi air yang aman merupakan hal terpenting bagi kesehatan manusia. Penelitian Shariq M et al., (2016) yang menguji 50 sampel air minum di sekitar universitas Moradabad, India, sebanyak 22 sampel (44\%) positif mengandung koliform.

\section{Higiene bahan teh}

Bahan teh merupakan merek bahan yang digunakan sebagai bahan baku es teh. Bahan the memang tidak mempengaruhi keberadaan bakteri Eschericia coli, namun ditakutkan bahan teh yang tidak terdaftar di lembaga perizinan akan menentukan keamanan produk tersebut. Bahan pangan yang tidak terdaftarkan ditakutkan mengandung bahan yang dilarang penggunaannya dalam pangan sehingga akan berakibat buruk bagi kesehatan (BPOM No 29 Tahun 2013).

\section{Kondisi fisik gula}

Gula disimpan di dalam toples yang tertutup. Berdasarkan penelitian Sofiana (2012) tidak terdapat hubungan antara penyimpanan bahan makanan terhadap keberadaan bakteri Eschericia 
coli di dalam makanan. Namun penyimpanan bahan makanan yang salah dapat membuat kerusakan pada bahan makanan dan membuat bahan makanan menjadi cepat busuk. Penyimpanan bahan makanan kering seharusnya berada pada suhu yang sejuk, udara kering, ventilasi baik, ruangan bersih dan kering, serta lantai dan dinding yang tidak lembab (Bartono, 2005).

\section{Jenis es batu}

Tiga Puluh pedagang yang menggunakan es batu rumah tangga, sebanyak 28 pedagang $(93,3 \%)$ memilih membeli. Alasan pedagang membeli es batu rumah tangga karena tidak sempat untuk membuat es batu sendiri, harganya murah, dan lebih bersih dibandingkan es batu lainnya. Dari 28 pedagang yang membeli es batu rumah tangga, sebanyak 5 sampel es $(17.8 \%)$ didapatkan hasil positif bakteri Eschericia coli. Kondisi ini masih tidak dapat dikatakan memenuhi karena bakteri Eschericia colisendiri tidak seharusnya berada di dalam minuman dengan batas maksimum 0/100 $\mathrm{ml}$ minuman. Hal ini disebabkan pedagang tidak mengetahui sumber pembuatan es batu rumah tangga tersebut. Penelitian ini pernah dilakukan oleh Hadi et al., 2014 yang menguji koliform pada 9 sampel es batu rumah tangga. Hasil menunjukkan bahwa keseluruhan sampel positif mengandung koliform. Semua pedagang es batu memang memasak air terlebih dahulu lalu dimasukkan ke dalam plastik. Namun pemasakan dilakukan tidak sampai mendidih sehingga kemungkinan bakteri tidak sampai mati.

Pedagang yang membuat es batu sendiri beralasan karena sudah memiliki kulkas sendiri dan mempunyai waktu untuk membuat es batu. Namun 1 dari 2 pedagang yang membuat es batu sendiri mengaku bahwa mereka membuat es batu menggunakan air bersih yang telah direbus terlebih dahulu. Sementara 1 pedagang lainnya membuat es batu dengan air bersih tanpa direbus terlebih dahulu. Hal ini tidak dibenarkan karena air bersih tidak diperuntukkan sebagai air minum. Proses pembekuan es tidak langsung membunuh bakteri. Bakteri Eschericia coli tumbuh baik pada suhu $8^{\circ} \mathrm{C}-46^{\circ} \mathrm{C}$.bila berada dibawah temperatur minimum maupun sedikit diatas temperatur maksimum, bakteri ini tidak segera mati, melainkan mengalami dorman (Misnadiarly, 2014). Hasil pengujian sampel produk pada es batu yang menggunakan air mentah menunjukkan adanya keberadaan Eschericia coli. Jenis es batu lain yang digunakan pedagang adalah es batu kristal. Alasan pedagang menggunakan es batu kristal adalah karena lebih bersih, praktis dan tidak perlu memotong walaupun harganya lebih mahal. Sebanyak 2 jenis es batu kristal yang digunakan pedagang, 1 sampel diketahui positif bakteri Eschericia coli. Walaupun es batu kristal diperuntukkan untuk minuman, namun tidak dapat dipungkiri bahwa cara pembuatannya pun dapat tidak memenuhi persyaratan Higiene dan sanitasi sehingga masih ditemui bakteri pada produk minuman. Jenis es batu lainnya yang digunakan yakni es batu balok. Sebanyak 2 pedagang menggunakan es batu balok dalam pembuatan es. Alasannya adalah adalah karena lebih murah dan es batu tidak cepat cair. Berdasarkan pengujian laboratorium, diketahui bahwa salah satu sampel tersebut positif mengandung Bakteri Eschericia coli. Penelitian serupa pernah dilakukan oleh Eliyanti (2014) yang membandingkan jumlah kandungan bakteri Eschericia coli pada tiga jenis es yaitu es batu rumah tangga, es batu kristal, dan es batu balok. Jumlah bakteri terbesar ada pada es batu balok yaitu 96/100ml sampel, sementara es batu Kristal 15/100ml sampel, dan es batu rumah tangga 15/100ml sampel. Kandungan bakteri pada es batu balok yang besar kemungkinan karena sumber air yang tidak bersih, proses pengolahan, penyimpanan, dan pendistribusian yang tidak higienis (Eliyanti, 2014). 


\section{SIMPULAN}

Hasil pengujian terhadap 34 sampel es teh di warung menunjukkan bahwa sebanyak 8 warung $(24 \%)$ positif mengandung bakteri Eschericia coli. Keberadaan bakteri Eschericia coli di dalam sampel es teh ini menunjukkan masih adanya faktor higiene dan sanitasi yang kurang. Kondisi sanitasi peralatan masih sebagian besar masih kurang baik terutama pada proses pencucian masih terdapat pedagang yang tidak memakai sabun/detergen saat mencuci peralatan, proses pencucian menggunakan 2 ember dan dicelupkan secara berulang-ulang walaupun air yang digunakan adalah air sesuai peruntukkannya.

Kondisi higiene bahan minuman sudah baik. Para pedagang sudah menggunakan air yang diperuntukkan bagi air minum namun masih terdapat pedagang yang menggunakan air sumur tanpa melalui pemasakan terlebih dahulu sebagai bahan pembuatan es teh, untuk bahan teh, terdapat 1 dari 34 pedagang yang menggunakan teh dengan merek yang tidak terdaftar di lembaga perizinan, keseluruhan gula yang digunakan telah memenuhi yaitu kondisi baik, tidak rusak, dan tidak membusuk. Untuk penggunaan es batu, sebagian besar telah menggunakan es batu rumah tangga namun masih terdapat pedagang yang menggunakan es batu balok dan ada juga pedagang yang membuat es batu sendiri dengan air mentah.

\section{DAFTAR PUSTAKA}

Adams M dan Motarjemi Y, 2003. Dasardasar Keamanan Untuk Petugas Kesehatan (Basic Food Safety For Health Workers). Jakarta: EGC.

Ademi BT dan Rinanda T, 2011. Deteksi Cemaran Escherichia coli Pada Daging Burger Penjual Kaki Lima Di Desa Kopelma Darussalam Dan Restoran Cepat Saji Di Banda Aceh. Jurnal Kedokteran Syiah Kuala.
11(3): 134-142. Fakultas Kedokteran Universitas Siah Kuala.

Agustina NL, 2011. Hubungan Antara Higiene Penjamah Dan Sanitasi Makanan Dengan Keberadaan Bakteri Escherichia coli (Studi Pada Warung Jus Buah Di Sekitar Kampus UNNES, Sekaran Gunungpati Semarang Tahun 2011). Skripsi. Universitas Negeri Semarang.

Azari JT, 2013. Studi Komparatif Pencucian Alat Makan Dengan Perendaman Dan Air Mengalir Terhadap Jumlah Kuman Pada Alat Makan Di Warung Makan Bu Am Gonilan. Artikel Publikasi Ilmiah. Surakarta: Universitas Muhammadiyah Surakarta.

BPS 2015. Mewujudkan Aksesbilitas Air Minum dan Sanitasi yang Aman dan Berkelanjutan Bagi Semua. Jakarta: $\mathrm{Cv}$ Dharmaputra.

Bartono dan Ruffino, 2005. Food Product Management di Hotel dan Restoran. Yogyakarta: Andi.

Cabral JPS, 2010. Water Microbiology. Bacterial Pathogens and Water. International Journal of Environmental Research and Public Health. 7(10): 3657- 370. [https:// doi: 10.3390/ijerph7103657]

Depkes RI, 2006. Modul Khursus Higiene dan Sanitasi Makanan dan Minuman. Jakarta: Departemen Kesehatan Republik Indonesia Ditjen PPM dan PLP.

Depkes RI, 2004. Higiene Sanitasi Makanan dan Minuman. Dirjen PPM dan PL. Jakarta

Hadi B, Bahar E, Semiarti R, 2014. Uji Bakteriologis Es Batu Rumah Tangga yang digunakan Penjual Minuman di Pasar Lubuk Buaya Kota Padang.Jurnal Kesehatan Andalas. 3(2): 119-122. Fakultas Kedokteran Universitas Andalas.

Isnawati, 2012. Hubungan Higiene Sanitasi Keberadaan Bakteri Coliform Dalam Es Jeruk Di Warung Makan Kelurahan Tembalang Semarang. 
Jurnal Kesehatan Masyarakat. 1(2): 1005-1017.

Kepmenkes RI No 715 Tahun 2003

Tentang Persyaratan Higiene Sanitasi Jasaboga.

Kurniadi, Saam Y, Afandi, 2013. Faktor Kontaminasi Bakteri E. Coli Pada Makanan Jajanan Dilingkungan Kantin Sekolah Dasar Wilayah Kecamatan Bangkinang. Jurnal Ilmu Lingkungan. 7(1): 28-37. Fakultas Kedokteran Universitas Riau.

Kusumawati T dan Yudhastuti R, 2013. Higiene Dan Sanitasi Makanan Nasi Krawu Di Kecamatan Gresik Kabupaten Gresik. Jurnal Kesehatan Lingkungan. 7(1):38-44. Fakultas Kesehatan Masyarakat Universitas Airlangga

Marrisa N dan Arifin AY, 2014. Higienitas Peralatan Makan Berdasarkan Keberadaan Salmonella Sp. Di Warung Makan Kota Banda Aceh.Jurnal Penelitian Kesehatan. 1(1): Departemen Kesehatan Republik Indonesia Badan Penelitian dan Pengembangan.

Marpaung MDO dan Marsono BD, 2013. Uji Kualitas Air Minum Isi Ulang di Kecamatan Sukolilo Surabaya Ditinjau dari Perilaku dan Pemeliharaan Alat. Jurnal Teknik Pomits. 2(2): 166-170. FTSP Institus Teknologi Sepuluh Nopember (ITS).

Marsono, 2009. Faktor-Faktor yang Berhubungan dengan Kualitas Bakteriologi Air Sumur Gali di Pemukiman. Skripsi Online.Diakses 28 Agustus 2012.

Misnadiarly dan Husjain D, 2014. Mikrobiologi untuk Klinik dan Laboratorium. Jakarta: PT Rineka Cipta.

Peraturan Kepala Badan Pengawas Obat Dan Makanan Republik Indonesia Nomor 29 Tahun 2013 Tentang Rencana Strategis Badan Pengawas Obat Dan Makanan Tahun 20102014
Peraturan Menteri Kesehatan Nomor 1098 Tahun 2003 tentang Persyaratan Higiene dan Sanitasi Rumah Makan dan Restoran.

Puspitasari S dan Mukono J, 2013. Hubungan Kualitas Bakteriologis Air Sumur Dan Perilaku Sehat Dengan Kejadian Waterborne Disease Di Desa Tambak Sumur, Kecamatan Waru, Kabupaten Sidoarjo. Jurnal Kesehatan Lingkungan. 7(1): 76-82. Fakultas Kesehatan Masyarakat Universitas Airlangga.

Putri ND, 2015. Identifikasi Bakteri Eschericia coli Pada Es Batu yang Dijual Warung Nasi di Kelurahan Pisangan Tahun 2015.Laporan Penelitian. Unversitas Islam Negeri Syarif Hidayatullah Jakarta.

Rahmani N dan Handayani S, 2016. Kontaminasi Bakteri Eschericia Coli Pada Makanan Dan Minuman Penjual Jajanan Di Lingkungan Pendidikan Muhammadiyah Limau, Jakarta Selatan. ARKEMAS. 1(1): 2535. Fakultas Ilmu Kesehatan Universitas Muhammadiyah Prof Hamka Jakarta.

Sawong K, Andrias D, Muniroh L, 2016. Penerapan Higiene Sanitasi Jasa Boga Pada Katering Golongan A2 Dan Golongan A3 Di Kota Palangka Raya Provinsi Kalimantan Tengah.Media Gizi Indonesia. 11 (1): 1-10. Fakultas Kesehatan Masyarakat Universitas Airlangga.[https://doi:10.20473/mgi. v11i1.1-10]

Shariq M, Singh S, Farooq U, Dhariyal KK, Singh K, dan Kaur N, 2016. Presumptive Coliform Count in Water Sample Collected from Different Sites of a University, Moradabad, Uttar Pradesh, India. International Journal of Scientific Study. 3(12):91-96. [https:// DOI: 10.17354/ijss/2016/128]

Sofiana E, 2012.Hubungan higiene dan sanitasi dengan kontaminasi Eschericia coli pada jajanan di 
sekolah dasar kecamatan tapos depok tahun 2012. Skripsi. Universitas Indonesia.

Tumelap HJ, 2011. Kondisi Bakteriologik Peralatan Makan Di Rumah Makan Jombang Tikala Manado.Jurnal Kesehatan Lingkungan. 1(1): 20-27. Kemenkes Manado.

Yanti E, 2014. Studi Tentang Bakteri Escherichia coli Dan Logam Berat Dalam Es Batu Yang Digunakan Pedagang Di Sepanjang Pantai Purus
Kota Padang.Skripsi. (STKIP) PGRI Sumatera Barat Padang.

Yunus S, Umboh J, Pinontoan O, 2015. Hubungan Personal Higiene dan Fasilitas Sanitasi dengan Kontaminasi Escherichia Coli Pada Makanan di Rumah Makan Padang Kota Manado Dan Kota Bitung.Artikel Penelitian. 5(2): 210220. Manado: Universitas Sam Ratulangi. 